Arch. hist. jap. Vol. 18, n. 4 (January 1960).

P. $545-564$.

Anat. Labor. of Prof. H. SETO, Tohoku University, Sendai.

\title{
Histological Studies on the Innervation of the Esophagus in Formosan Macaque.
}

\author{
台湾猿の食道の神経分布に関する組織学的研究。
}

Toshiyuki YAMAMOTO 山本 敏 行.

(Received September 17, 1959.)

The present author has been engaged for some years in a series of histological studies on the innervation, especially the sensory innervation of the digestive organs of the monkey, in collaboration with his co-workers, and has already reported on his detailed observations on the rectum, pars pylorica of the stomach, duodenum, pancreas, pancreatic and bile ducts, lip, soft palate and anus, bringing out many interesting results (YAMAMOTO 1957 and 1959; YAMAMOTO et al. 1958 and 1959). Lately, the nerve supply of the esophagus was his object of study reported hereunder.

Many works on the innervation of the esophagus have been published, especially from this laboratory. E. g., SADA (1942) has achieved very reliable and interesting results in his study on the esophagus of man, SUGAMATA (1955) in that on dog's, HOSHINA (1958) in that on snapping turtle's and ABE (1959) in that on goat's esophagus. The present author undertook a histological study of the esophageal nerves of the Formosan macaque, and discussed the findings in comparison with the results obtained by these authors.

The esophagi of adult Formosan macaques (Macacus cyclopis) used as materials were first fixed in $10 \%$ neutral formol solution for a long time, cut into $40 \mu$ longitudinal or transverse frozen sections and stained by SETO's silver impregnation method.

\section{Individual Findings.}

There are some reports on the fine structure of the mammalian esophagi since the days of GOETSCH (1910) and BARTLAKOWSKI (1930) published a comparative-anatomical study on the esophagi of many species of Prosimiae and Anthropoideae. I will also speak a word on my individual findings on the microscopical anatomy of the esophagus of the Formosan macaque, before entering upon the main theme of the nerve supply, especially the sensory nerve supply of the part.

The epithelium of the esophageal mucosa in Formosan macaque, as shown in Fig. 1, is a thick stratified flat one of more than 20 layers, as in the other mammals studied hitherto. Its surface is cornified to about the same degree as in the human esophagus, as described by GOETSCH (1910) and STIEVE (1931), namely, a little keratohyalin is contained in the superficial layers of the epithelium, but even in the topmost layer, the flat epithelial cells retain their nuclei intact. The 


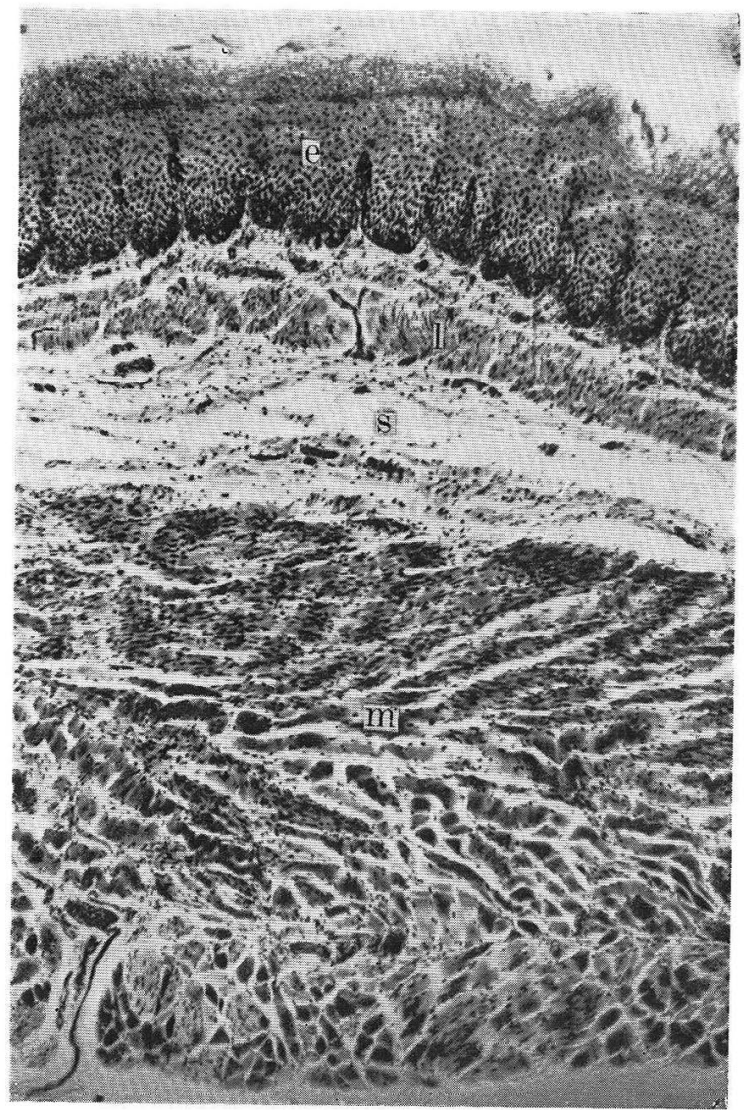

Fig. 1. A cross section of the mid-part of the esophagus of a Formosan macaque. $e$ thick stratified flat epithelium, $l$ lamina muscularis mucosae, $s$ submucosa, $m$ tunica muscularis. SETO's silver impregnation. Photo $\times 60$.

lamina propria mucosae is very thin, consists of a rather dense, fibrous connective tissue, and contains lymphocytes and sometimes small lymphatic nodules in it. The papillae growing out of the lamina propria into the epithelium are not much well developed (Fig. 1), very lean papillae being found arranged rather regularly. As the lower end of the esophagus is approached, the papillae become larger-sized, and some come to have secondary papillae.

The muscularis mucosae running longitudinally beneath the lamina propria is ill developed in the upper portion of the esophagus, forming not a continuous sheet there, but in the middle and the lower portions, it forms a thick layer (Fig. 1). This muscularis mucosae often sends out small muscle fibre bundles into the lamina propria. The boundary on the mucous membrane between the esophagus and the stomach at the cardiac orifice is very distinct. No such islets of the gastric mucosa as found in the lower part of the human esophagus could be found in my macaque 
specimens, as little as in many other species of monkeys (BARTLAKOWSKI 1930),

A considerably thick submucosa of a loose connective tissue containing a small number of fat cells and well-developed blood vessels lines the muscularis mucosae. This layer usually contains esophageal glands very unequally developed in defferent animals. In dog, for example, the glands are found in a considerable number over the entire length of the esophagus, in man in a small number only in the upper part of it, but never in the esophagi of nearly all the rodents and some of the ungulates, carnivores and marsupials as described by OPPEL (1897) and GOETSCH (1910). BARTLAKOWSKI (1930) found such glands in the esophagi in variable numbers in most of the Prosimiae and the Anthropoideae he examined, only in the upper half of the esophagus in most cases, but in 4 cases of unspecified monkeys he found no esophageal gland at all. It is of interest that $I$ could not find any esophageal gland, even in the upper part of the esophagus of the Formosan macaque.

In the esophagus of monkeys, the tunica muscularis was found to consist of striated muscle fibres in the upper part of the esophagus, and to be gradually replaced by a smooth musculature as the lower part is reached. BARTLAKOWSKI (1930)

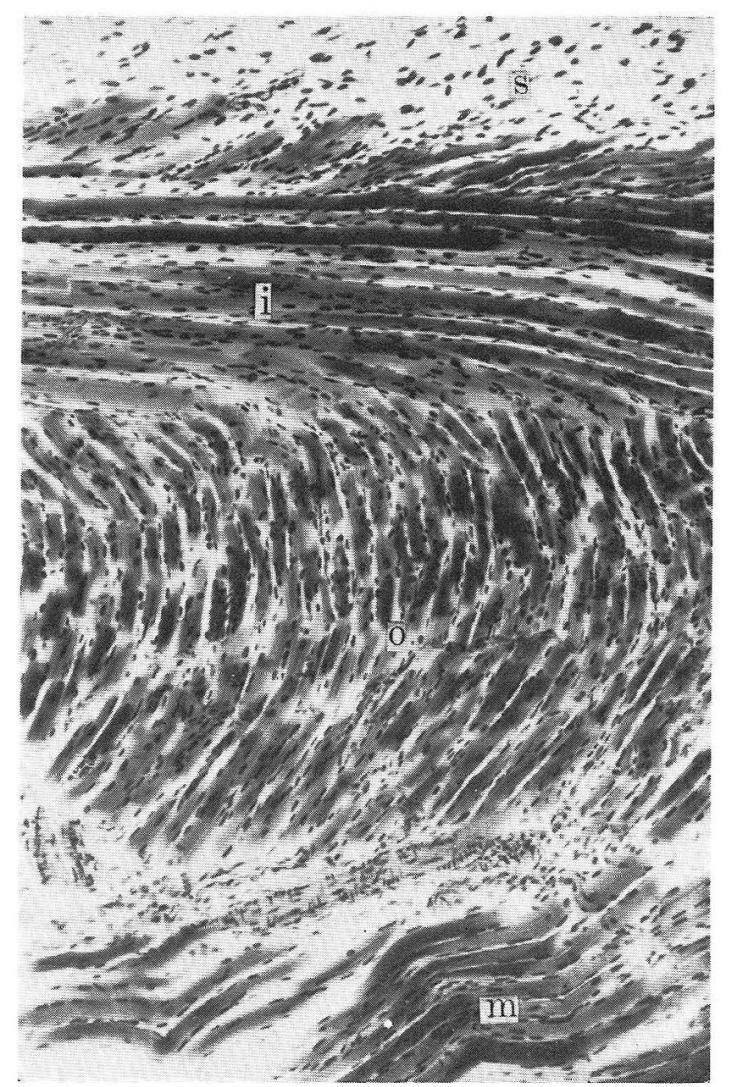

Fig. 2. A longitudinal section of the upper part of the esophagus of a Formosan macaque. $i, o$ and $m$ inner, outer and vutermost layers of the tunica muscularis of striated nature. $s$ submucosa. Details in the text. Same staining. Photo $\times 100$. 
describes the transition of one of the muscle tissue into the other in primates as follows. The level where the striated muscle fibres disappear gradually goes down as the animal goes up in the evolutionary scale from prosimiae to anthropoid apes. For example, while Lemur macaco, the striated muscle fibres are limited to the upper $1 / 4$ of the esophagus, in anthropoid apes they were found in a small number even in the lower 1/8, in some of the apes reaching even the cardia. In Macacus cynomolgus and Macacus rhesus, no striated muscle fibres are said to reach into the lower $1 / 8$ of the esophagus. In my Macaus cyclopis, the transition between the two kinds of muscle tissue was found somewhat different from that in those macaques, for in the former, the smooth muscle fibres begin to be seen before coming down to the middle of the esophagus, while the striated muscle fibres disappear on a level higher than the upper limit of the lower $1 / 6$ of the esophagus, so that in this portion both the inner and the outer layers of the muscularis are composed of sheer smooth muscle fibres.

In my materials, too, the muscularis consists of an inner circular and an outer longitudinal layers, but in the upper part of the esophagus, as shown in Fig. 2, the boundary between the two layers was somewhat indistinct, the muscle fibres have lost the regularity in their arrangement, running somewhat obliquely, and especially in the vicinity of the transitional part into the pharynx, it appeared as if the inner layer was oriented longitudinally and the outer layer circularly. In some sites, a thin outermost longitudinal layer was seen outside the two layers. As reported by BARTLAKOWSKI (1930) and YANOHARA (1955), the inner layer was thicker than the outer, the former swelling up sphincter-wise at the transitional part into the cardia.

As shown in the detailed study by RIEGELE (1926), the nerve fibres coming into the esophagus of monkeys originate in the cervical and the thoracic parts of the sympathetic trunk and the vagal nerves. The vagal nerves contain thick myelinated somato-motor fibres and still thicker sensory fibres, besides fine parasympathetic fibres; before attaining the esophageal wall, they ramify into fine bundles, which run into the adventitia of the esophagus while undergoing crossing and anastomosis with the sympathetic nerve bundles, and form the so-called periesophageal plexus there. It is of interest that small ganglia containing multipolar ganglion cells are found in a number in the plexus (Fig. 3). The incoming nerve fibres, after forming the periesophageal plexus, penetrate the muscularis and come to play a part in forming AUERBACH's plexus.

In the esophagus below the middle part where the muscularis contains smooth muscle fibres and can be definitely divided into the inner circular and the outer longitudinal layers, AUERBACH's plexus is spread out in a plane in the connective tissue septum between the two layers and contain many ganglia. In particular, in the lower part where the muscularis is of sheer smooth musculature, this plexus is very well developed, nearly as well as in the stomach and the intestine. In the upper part, however, its development is very poor, the plexus being irregularly and loosely formed and the few small ganglia in it being not always located between the inner and the outer layers, but often within either of the layers, as the irregular arrangement of the muscle fibres entails (Fig. 4). 
Fig. 3. A ganglion formed in the periesophageal nerve plexus of a Formosan macaque. Same staining. Photo $\times 180$.

Fig. 4. A ganglion in AUERBACH's plexus formed in the outer layer of the tunica muscularis in the upper part of the esophagus of a Formosan macaque. Same staining. Photo

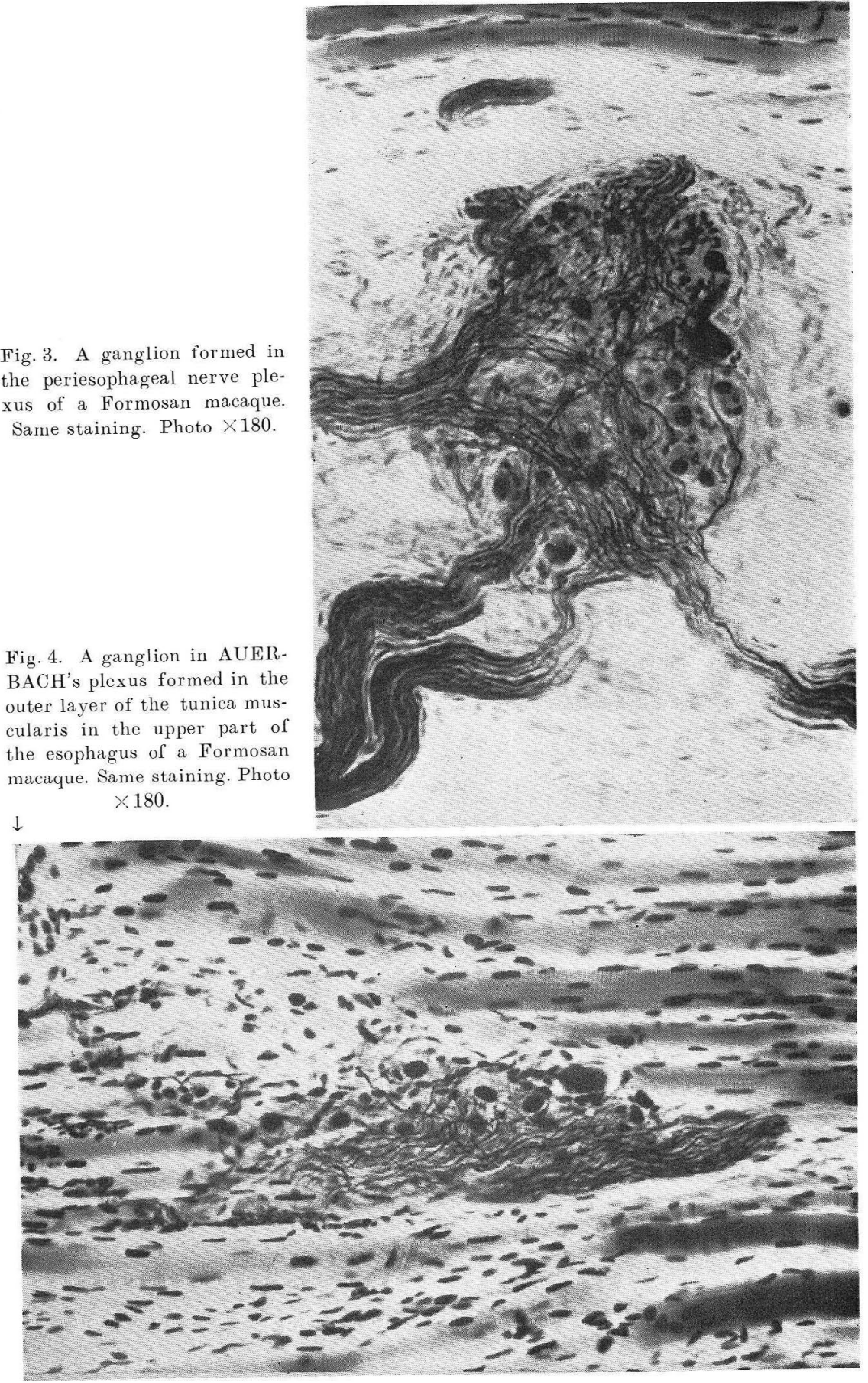


The ganglion cells found in AUERBACH's plexus, as described in the reports on the esophagus of man and some animals given out to date (LAWRENTJEW 1929, GREVING 1931, SADA 1942, STÖHR 1949 and 1957, ABE 1959), are always of DOGIEL's Type I, none of his Type II having been discovered (Fig. 5).

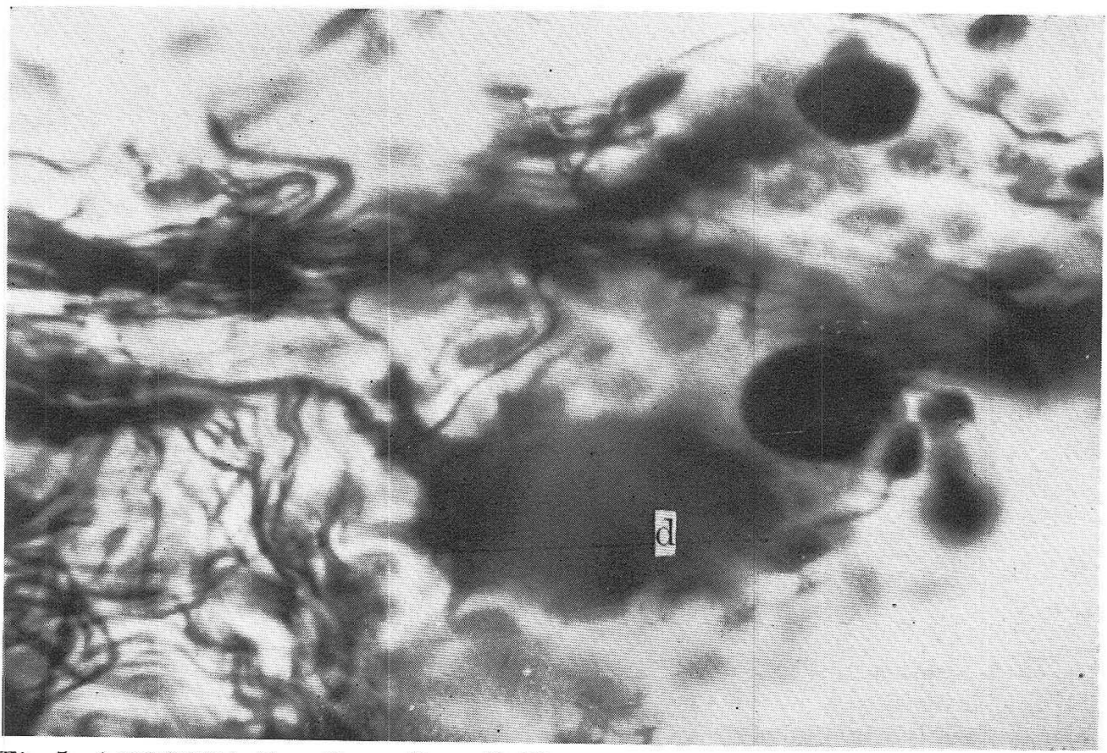

Fig. 5. A DOGIEL's Type I ganglion cell (d) found in AUERBACH's plexus of the esophagus of a Formosan macaque. Same staining. Photo $\times 840$.

These ganglion cells usually have more nerve processes than those in the stomach or the intestine, quite as JABONERO (1952) and STÖHR (1957) have observed in the human esophagus. Besides these multipolar cells, some seemingly apolar or infantile type cells with no demonstrable nerve process were also found in my macaque's esophagus, again quite as in the human (SADA 1942) and the canine (SUGAMATA 1955) esophagi.

MEISSNER's plexus is formed by far finer nerve bundles arranged more loosely than in AUERBACH's plexus, bundles of some thickness being found in a small number along the inside of the muscularis. Some ganglion cells were found in MEISSNER's plexus too of man and a few mammals by SABUSSOW (1913), LAWRENTJEW (1929), ISHISAWA (1936), SADA (1942) and SUGAMATA (1955), and I also found a few of them in the plexus of my simian specimens. These were always found in small groups near the muscularis and are mostly small apolar or infantile cells, but not rarely I found some DOGIEL's Type I cells among them. To my surprise, against all past descriptions to the contrary, these ganglion cells were fouud in a larger number in the upper part of the esophagus than its lower part where the ganglia are very scarce and are composed at most of one or a few ganglion cells, while in the upper part, as shown in Fig. 6, such large ganglia as comprising half a dozen to more than a dozen ganglion cells are not rare at all. Such a finding is of 


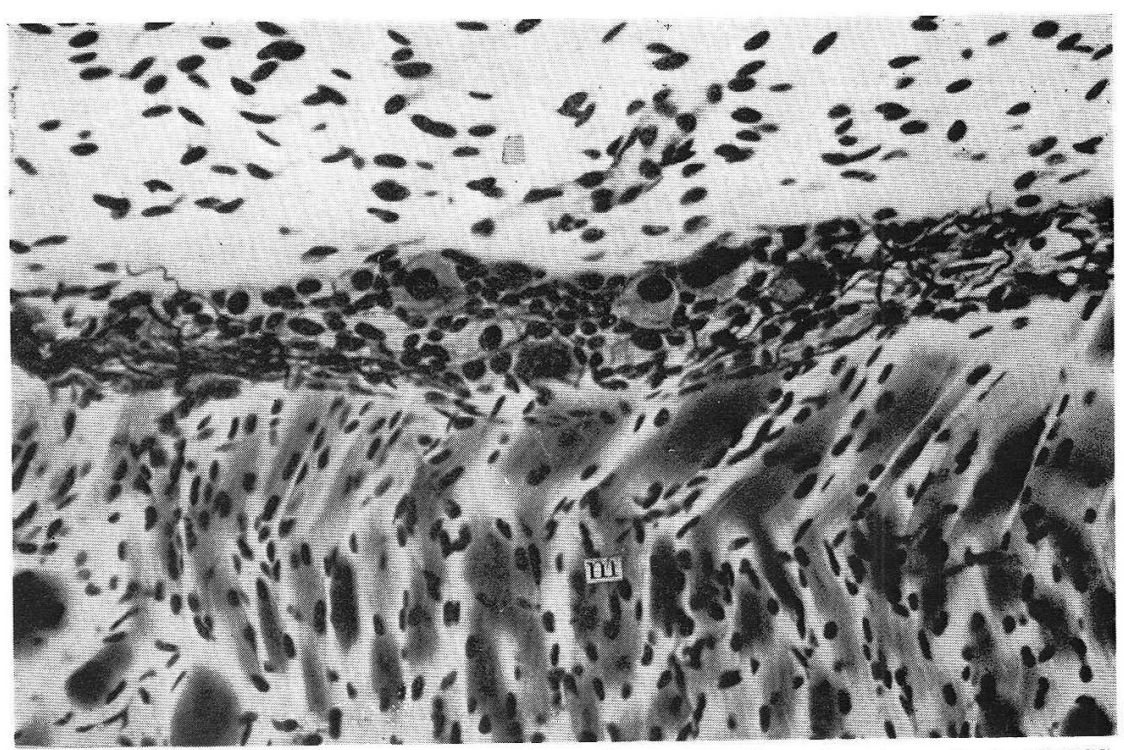

Fig. 6. A small ganglion composed of DOGIEL's Type I cells and apolar cells in MEISSNER's plexus formed in the upper part of the esophagus of a Formosan macaque. $m$ tunica muscularis, $s$ submucosa. Same staining. Photo $\times 180$.

deep interest, as nothing of the sort has ever been reported on hitherto.

The vegetative nerves distributed in the esophageal wall consist of very fine non-myelinated sympathetic fibres and only a little thicker parasympathetic fibres, which are thus easily distingushable from the far thicker myelinated sensory and somato-motor fibres. All the sympathetic and parasympathetic fibres here too form common terminal reticula of very fine fibrils (STÖHR) which stand in control by contact over all the tissue cells including the striated muscle fibres.

These terminal reticula are mesh-works of thin neurofibrillar net-strands containing elongated ellipsoid SCHWANN's nuclei and somewhat less elongated interstitial cell nuclei here and there. These neurofibrillar net-strands often run long winding courses in the submucosa and the lamina propria mucosae (Fig. 7). HARTING (1934) calls the areas run through by such winging net-strands 'Schlingenterritorien' and attributes a possible sensory nature to them, but in agreement with SADA (1942) and SUGAMATA (1955) of this laboratory, I am of the opinion that these belong to the terminal reticula and not to sensory terminations.

The thick myelinated motor nerve fibres supplied to the striated muscle fibres of the tunica muscularis of the esophagus run into the esophageal wall in company with vegetative and sensory fibres and distribute in the muscularis. These motor fibres run through the intermuscular connective tissue together with a small number of vegetative fibres and divide into a single fibre each upon nearing their terminal areas.

The motor terminations found in the esophagus in man are mostly of the type of terminaisons en grappes (SADA 1942), in goat of small terminaisons en plaques 


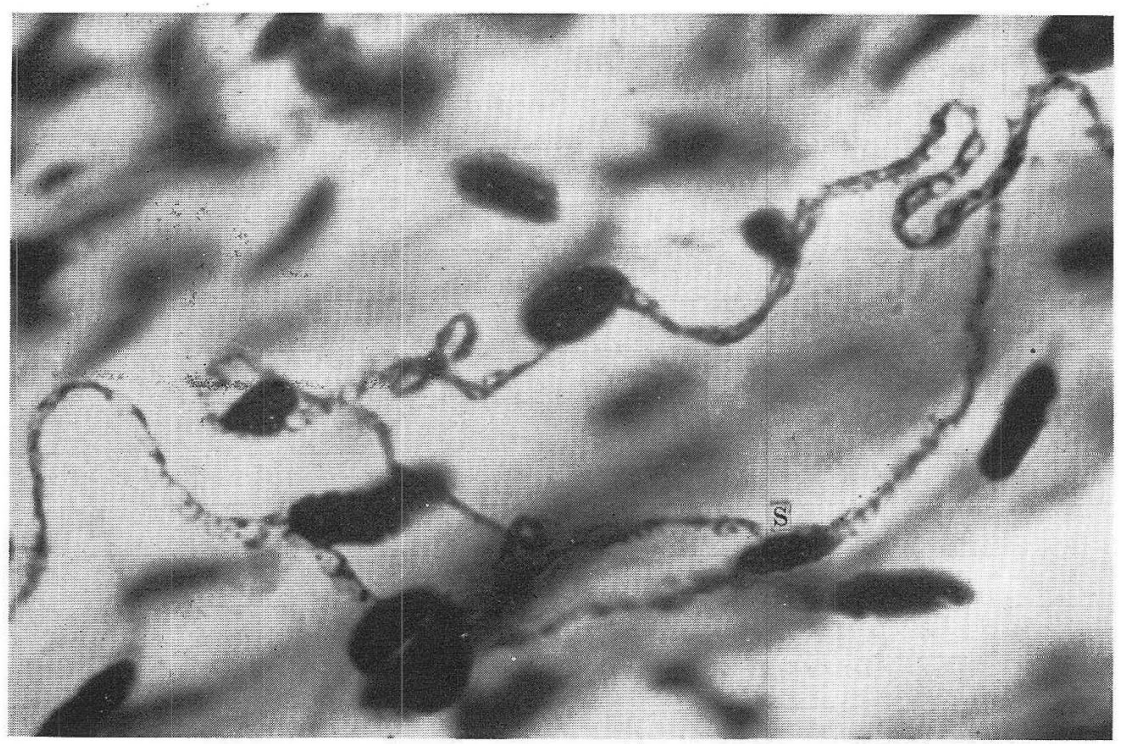

Fig. 7. Vegetative terminal reticulum formed in the propria mucosae of the esophagus of a Formosan macaque. $s$ SCHWANN's cell nucleus. Details in the text. Same staining. Photo $\times 840$.

(ABE 1959). In the Formosan macaque, they consist of about the same number of grape-like terminations rather resembling those in man but somewhat smaller in size and plate-like terminations somewhat larger than those in goat, as detailed below. In the former type of terminations, a thick stem fibre branches into several branch fibres, which, after running out more or less long winding courses, branch out into 2 or 3 very fine terminal fibres ending sharply but sometimes also in fine neurofibrillar enlargement. Their terminal areas have a very few specific round cell nuclei in them. Thus, in general appearance, these terminations resemble so many bunches of grapes (Fig. 8).

In the case of platelike terminations, the branch fibres branching out of the stem fibre end in a common end-plate, in form resembling those found in goat (Fig. 9 in ABE 1959). In size, however, those in my macaque's esophagus were about twice to thrice as large as those in goat. As shown in Fig. 9, a thick branch fibre ramifies into some subbranches which mostly subdivide into still finer terminal fibres ending sharply or in fibrillar enlargements or in small rings within a common end-plate with specific nuclei. The number of these nuclei are also twice or thrice as large as that of the nuclei in goat.

From the above findings, I was led to infer that the higher the animal in the evolutionary scale, the larger the number of the grape-like endings and the smaller the number of the plate-like endings among the motor-nerve terminations in the striated muscle tissue of the esophagus. By the way, I could find nothing of the kind so-called the glomerular motor endings by O'TTAVIANI (1937). I fear he has mistaken the undermentioned glomerular sensory terminations for motor endings. 


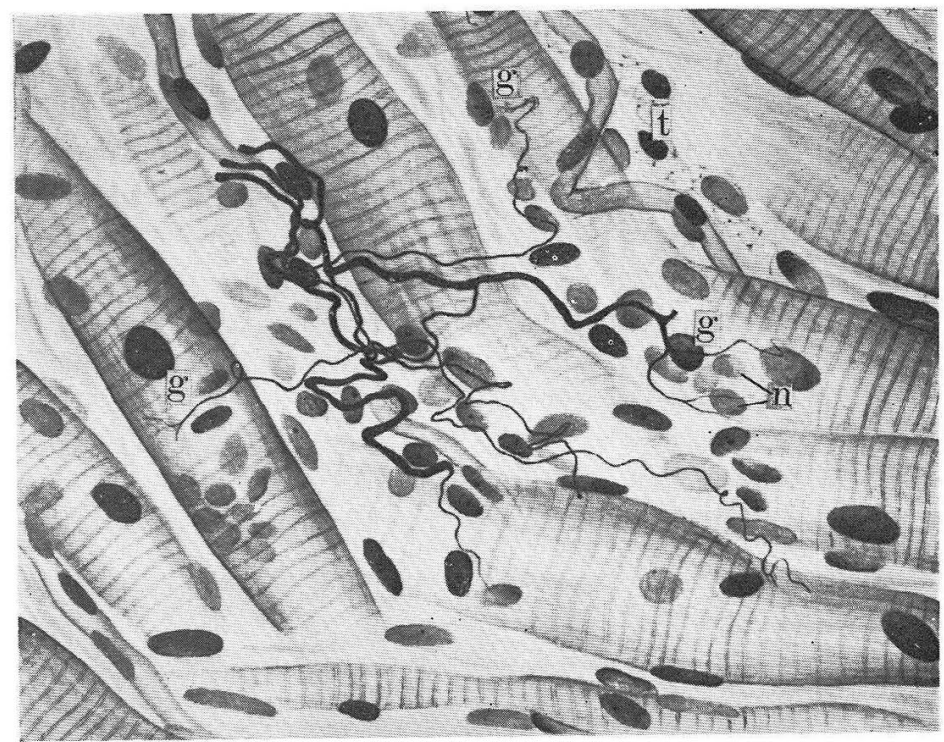

Fig. 8. Motor nerve fibres and their grape-like terminations $(g)$ composed of fine branch fibres formed in the striated muscle tissue of the upper part of the esophagus of a Formosan macaque. $n$ specific cell nuclei, $t$ vegetative terminal reticulum. Details in the text. Same staining. $\times 650$.

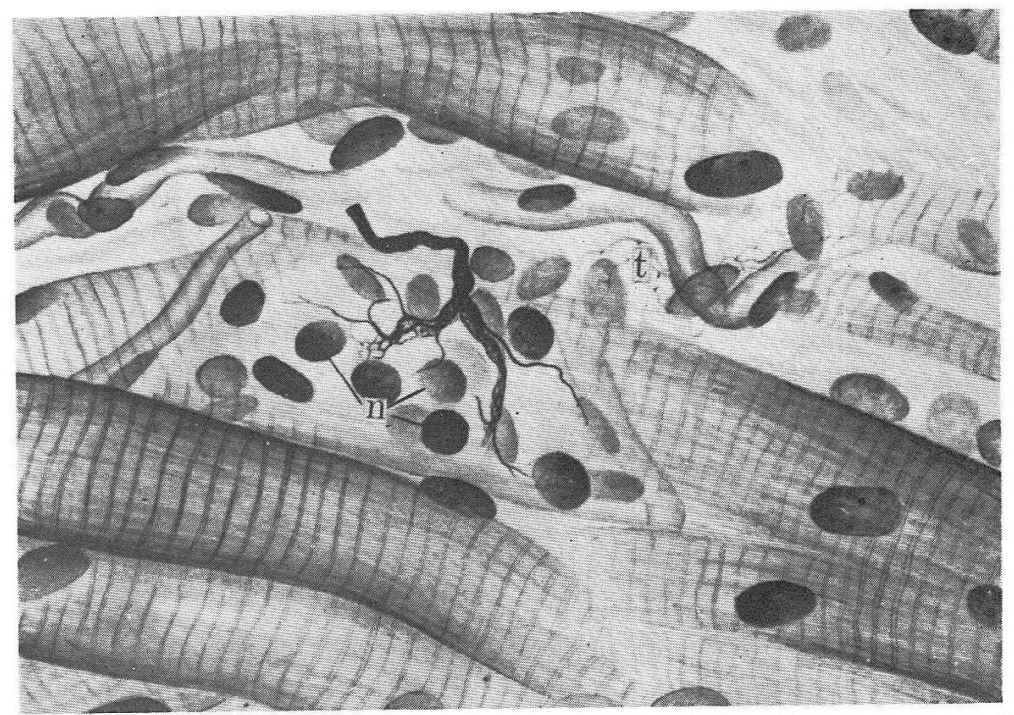

Fig. 9. A motor end-plate fomed in the striated muscle tissue of the upper part of the esophagus of a Formosan macaque. $n$ specific cell nuclei, $t$ vegetative terminal reticulum. Details in the text. Same staining. $\times 900$.

OTTAVIANI also reports on his discovery of some BOEKE's so-called accessory fibres of sympathetic origin in the striated muscle tissue of the esophagi of some 
mammals. In the Formosan macaque, however, I could frequently observe fine side branches of esophageal motor fibres running along with the thicker main branches into the same end-plates, but never a real vegetative fibre similarly ending in an end-plate in free termination, as claimed by BOEKE. Therefore, I am in one with HIRANO (1941), KUMAGAWA (1941), SADA (1942) and FUKUI (1955) in surmising that the BOEKE's so-called accessory fibres are nothing but fine side branches from motor fibres mistaken for vegetative or sympathetic fibres. Vegetative nerve fibres are of course distributed in striated muscles, too, but their terminal mode never deviated from the vegetative terminal reticula, in my specimens as well as in those of the other animals reported on by BOEKE (1933), SUNDER-PLASSMANN (1933), HIRANO (1941), KUMAGAWA (1941), SADA (1942) and ABE (1959). These terminal reticula innervate only by contact the muscle fibres, as shown in Fig. 10 as well as the blood vessels in the muscle tissue. Of course, the

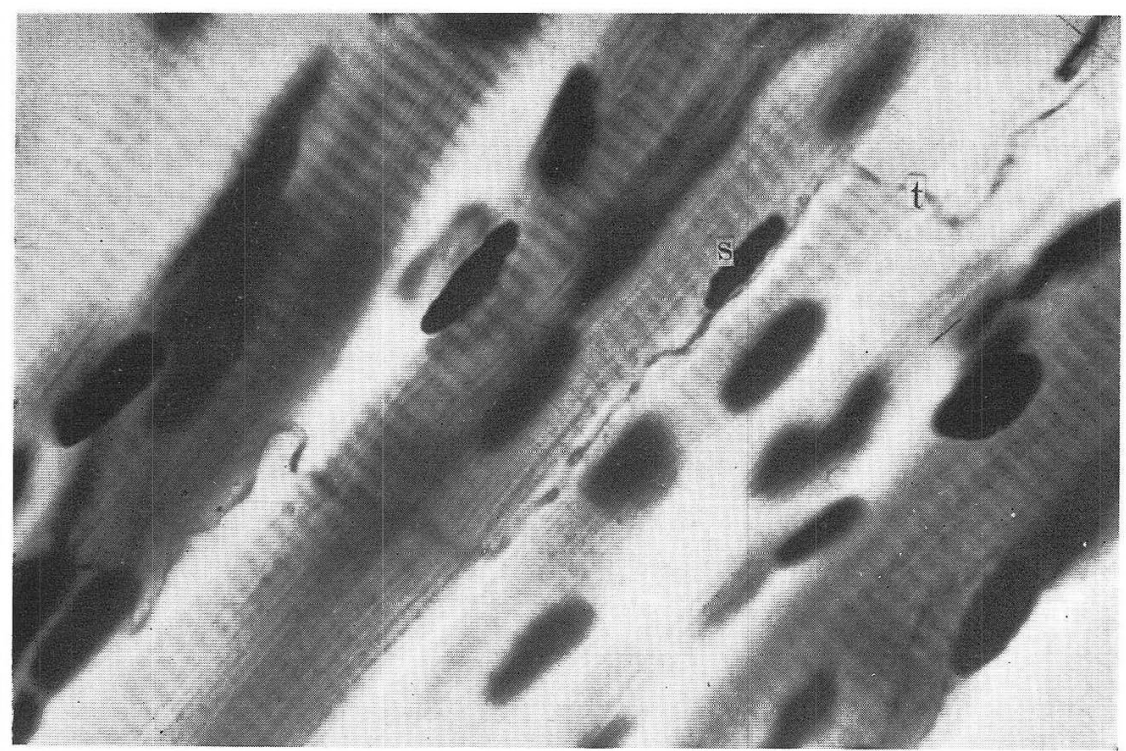

Fgi. 10. Vegetative terminal reticulum $(t)$ running along the striated muscle fibres of the tunica muscularis of the esophagus of a Formosan macaque. $s$ SCIIWANN's cell nucleus. Same staining. Photo $\times 840$.

density of distribution of terminal reticula in the striated muscle tissue is much lower than in the smooth muscle tissue.

The sensory fibres distributed in the esophagus of Formosan macaque being mostly myelinated fibres of very large size, they may be rather easily discriminated from the somewhat thinner motor fibres. These sensory fibres form their terminations, besides in all the layers of the esophageal wall also in AUERBACH's and MEISSNER's plexuses in it, as in man (SADA 1942).

In the muscularis of the esophageal wall, I found unbranched and simple branched sensory terminations showing something like glomerular arrangement. In 


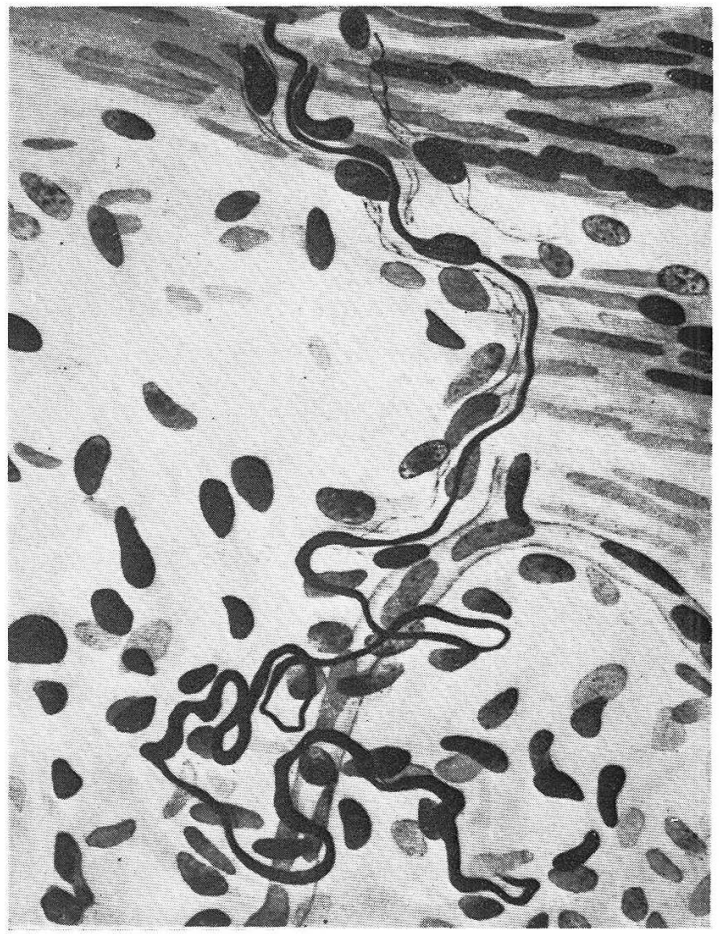

Fig. 11. A glomerular termination formed by an unbranched thick sensory fibre found in the intermuscular connective tissue septum of the tunica muscularis in the lower part of the esophagus of a Formosan macaque. Fine fibres are vegetative fibres. Details in the text. Same staining. $\times 800$

Figs. 11 and 12 are exemplified two unbranched terminations found in the muscularis of the lower part of the esophagus. As clearly illustrated in the figures, the terminal fibros consist in smooth-surfaced thick fibres showing frequent change in size and running frequently looped? courses, arranging themselves in more or less glomerular form and ending in blunt points. Specific cell nuclei are found here and there in their termial areas.

Examples of branched terminations formed in the muscularis are illustrated in Figs. 13 and 14. That shown in Fig. 13 was found in the muscularis composed of smooth muscle tissue in the mid-part of esophagus. Some of its branch fibres are thick and frequently change size but some others are very thin; the former show a glomerular arrangement as seen in the above mentioned unbranched terminations, but the latter do not show any such an arrangement, ending by slowly tapering off into sharp points. The terminal area of this termination too contain some specific cell nuclei.

The simple branched termination illustrated in Fig. 14 was found in the muscularis of the lower part of the esophagus. It is of interest that this is a simple 


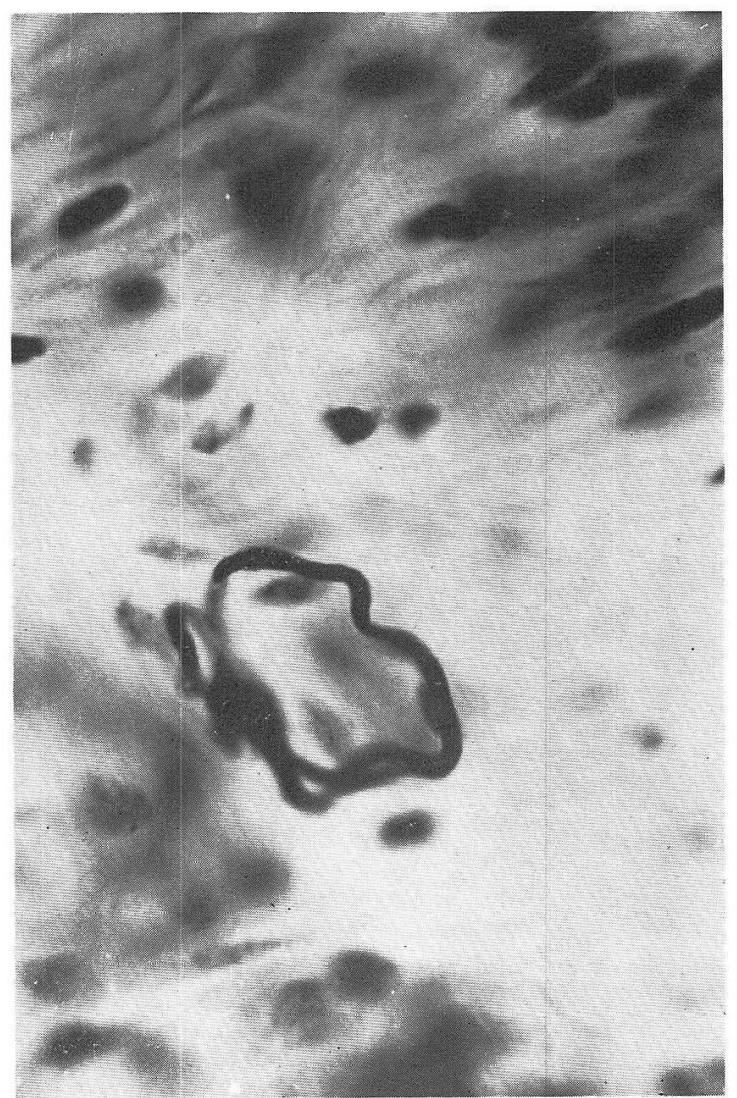

Fig. 12. Ditto. Same staining. Photo $\rtimes 840$.

branched termination formed by a rather thin branch fibre (b) sent out by a very thick stem fibre in its course. The branch fibre here subdivides into three sharpending finer terminal fibres, though the photograph fails to show them with adequate distinctness. The stem fibre describes a loop before running through the muscularis into the submucosa.

Besides the sensory terminations located in the muscularis composed of smooth muscle fibres described above, sensory terminations were found in the muscularis of striated muscle tissue of the esophagus, too. E. g., as shown in Fig. 15, a simple branched termination originating in a single thick myelinated fibre was found in the said tissue. Here, the stem fibre, after losing its myelin sheath, divides into 3 terminal fibres, which run wavy or looped courses and then slowly taper off into sharp points.

Thus, sensory terminations are found in the muscularis of the esophagus of Formean macaque also, but in comparison with those of man (SADA 1942), they are generally simpler in construction, such complex terminations with neurofibrillar leaf-like plates as found in the human esophagus being never seen in my macaque 
Fig. 13. A branched sensory termination found in an intermuscular connective tissue septum in the mid-part of the esophagus of a Formosan macaque. $t$ vegetative terminal reticulum. Details in the text. Same staining. $\times 800$, reduced to $6 / 7$.

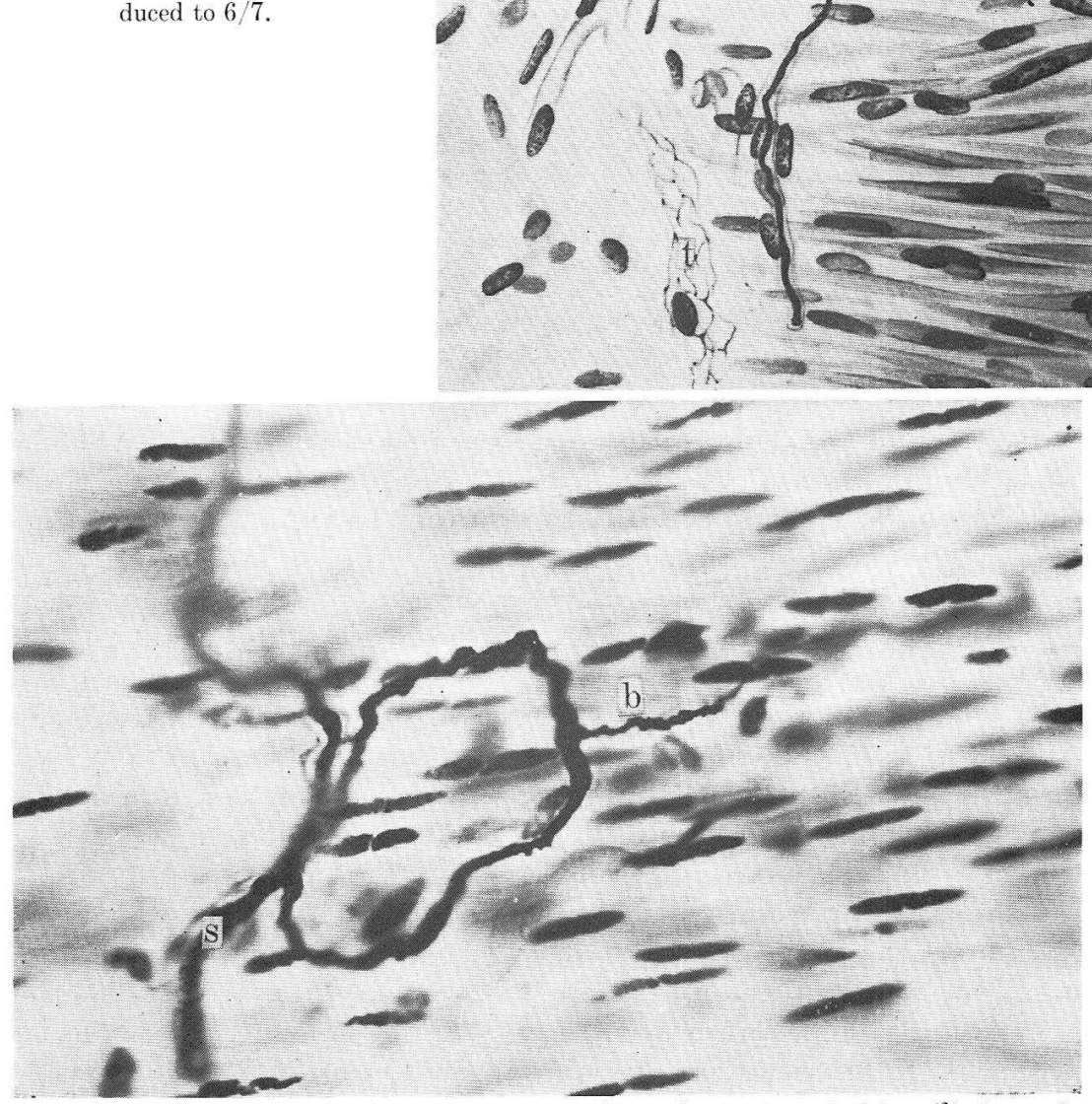

Fig. 14. A simple branched sensory termination formed by a branch fibre $(b)$ from the thick stem fibre (s) found in the tunica muscularis of the lower part of the esophagus of a Formosan macaque. A few sharply ending terminal fibres are not clarified in this photomicrograph; the stem sensory fibre runs towards the submucosa after showing a conspicuous looping course. Same staining. Photo $\times 600$. 


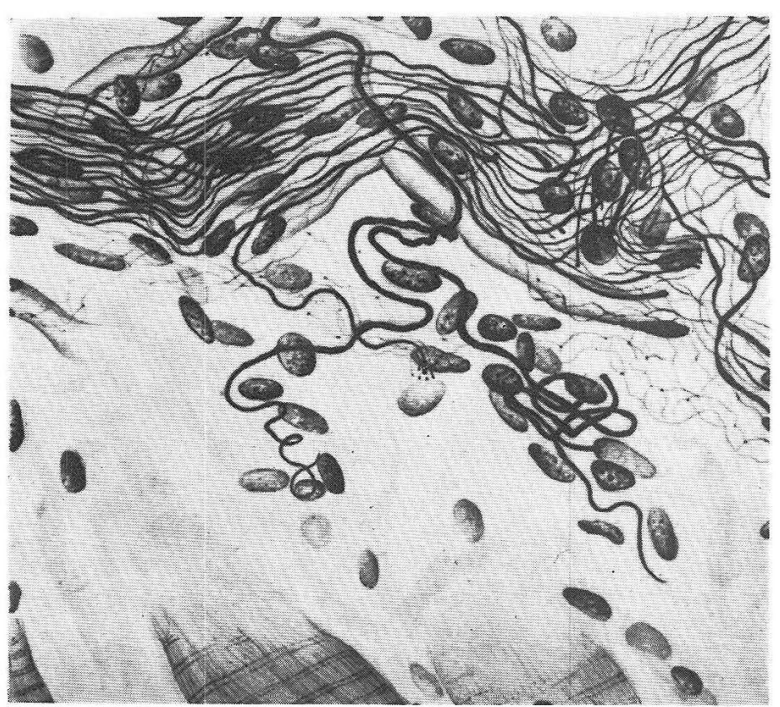

Fig. 15. A simple branched sensory termination formed in the intermuscular connective tissue septum of the tunica muscularis of striated nature of the upper part of the esophagus of a Formosan macaque. Details in the text. Same staining. $\times 800$.

specimens. SLAWIK (1942) seems to have found muscle spindles in the striated muscle tissue of the upper esophagus of man, but such nerve endings were not found in my macaque's esophagus, either.

It was SADA (1942) of this laboratory who first discovered sensory terminations in the ganglia of AUERBACH's and MEISSNER's plexuses in the human esophagus; since then NONIDEZ (1946) and SUGAMTA (1955) found the same in dog, KOLOSVA (1954) in human child, HOSHINA (1958) in snapping turtle, and ABE (1959) in goat. I also succeeded in unambiguously demonstrating complex branched sensory terminations very similar to those found in the human esophagus (SADA) in my specimens of Formosan macaque's esophagus. Such intraganglionic sensory terminations were found only in the upper portion of the esophagus, and in interesting contrast to those in man and the other animals cited above, were better developed in the ganglia of MEISSNER's plexus which are here comparatively better developed than those of AUERBACH's plexus.

Figs.16 and 17 show intraganglionic sensory terminations found in MEISSNER's plexus in the upper esophagus. Both are rather complex terminations, each originating in a very thick myelinated stem fibre. The branch fibres run peculiar looped courses while showing conspicuous change in size and spread out over a rather large area, frequently in glomerular arrangement (Fig. 17), before ending in blunt or sharp points. These terminations, however, are considerably simpler in construction than those in man (SADA 1942), but are of more or less higher complexity than those in dog (SUGAMATA 1955), snapping turtle (HOSHINA 1958) and goat (ABE 1959).

Sensory terminations are not absent in the submucosa and the lamina propria 


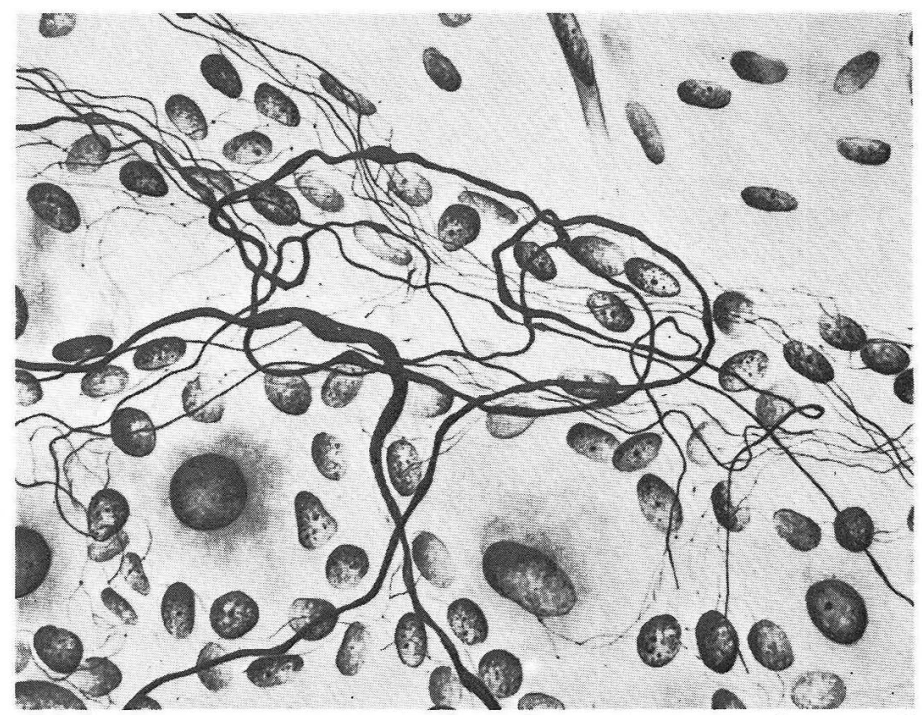

Fig. 16. A rather complex branched sensory termination found in a small ganglion in MEISSNER's plexus formed in the upper part of the esophagus of a Formosan macaque. Thin fibres are vegetative fibres. Details in the text. Same staining. $\times 800$, reduced to $6 / 7$.

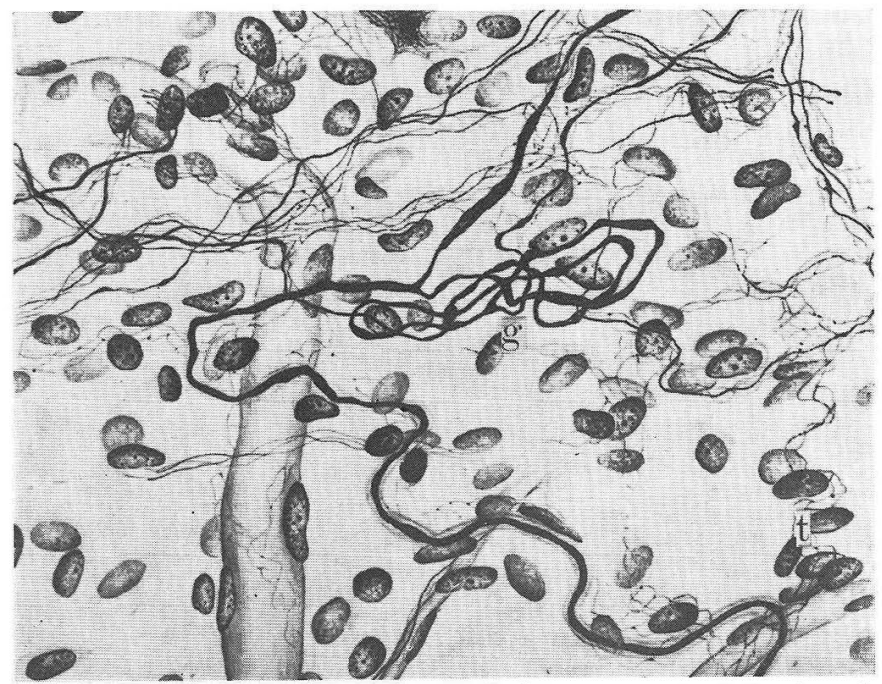

Fig. 17. Ditto. $g$ conspicuous glomerular arrangement of the branch fibres. Thin fibres are vegetative fibres, $t$ vegetative terminal reticulum. Same staining. $\times 800$, reduced to $6 / 7$.

mucosae of the esophagus of Formosan macaque, either, but these are nothing but unbranched and simple branched torminations. As shown in Fig. 18, the sensory fibres forming such terminations frequently run very peculiar snake-like serpentine courses, particularly often in the submucosa. Accordingly, these have been termed 


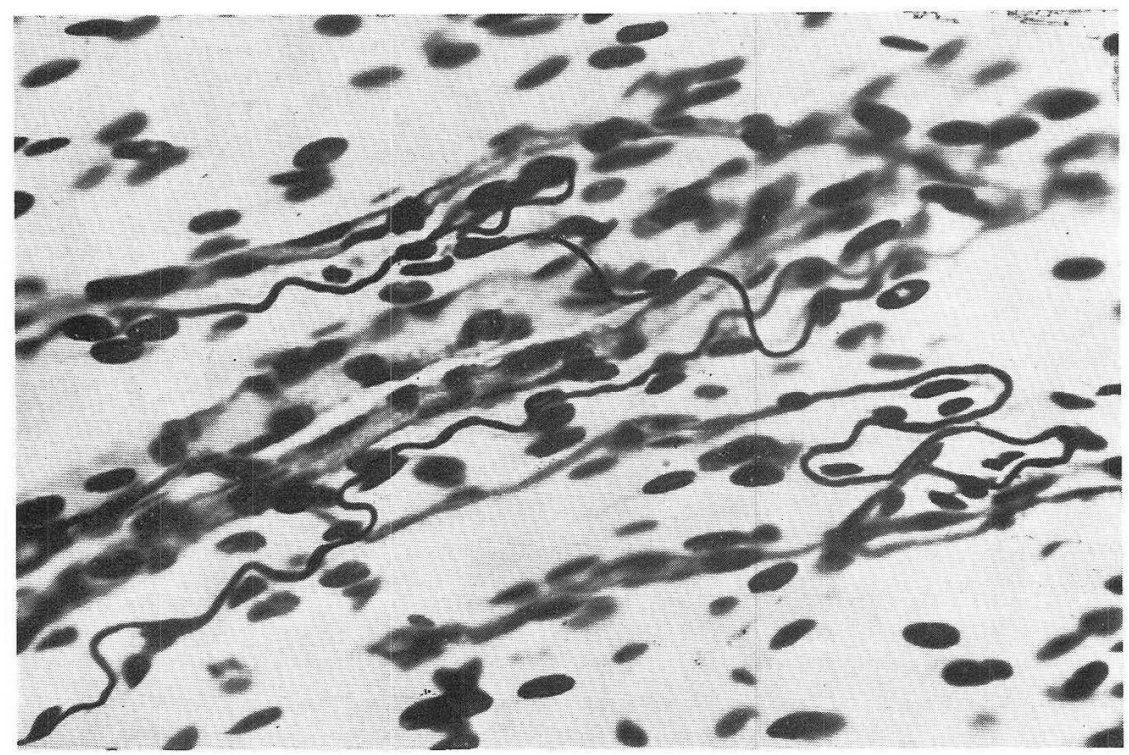

Fig. 18. An unbranched serpentine sensory termination found in the submucosa of the esophagus of a Formosan macaque. Details in the text. Same staining. Photo $\times 380$.

the serpentine terminations (SADA 1942, SUGAMATA 1955, ABE 1959).

In Fig. 19 are shown 2 bifurcated sensory terminations found subepithelially in the esophagus. The courses of their stem fibres are not very wavy and the pairs of terminal fibres end sharply just beneath the epithelium. Fig. 20 is a photomicro-

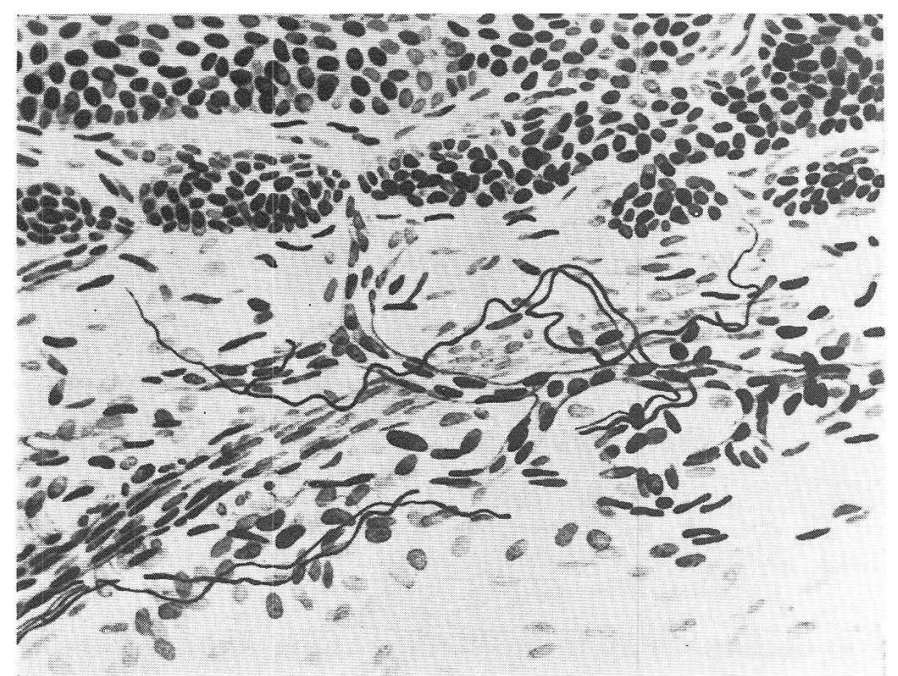

Fig. 19. Two bifurcated sensory terminations formed in the lamina propria mucosae of the esophagus of a Formosan macaque. Details in the text. Same staining. $\times 300$. 


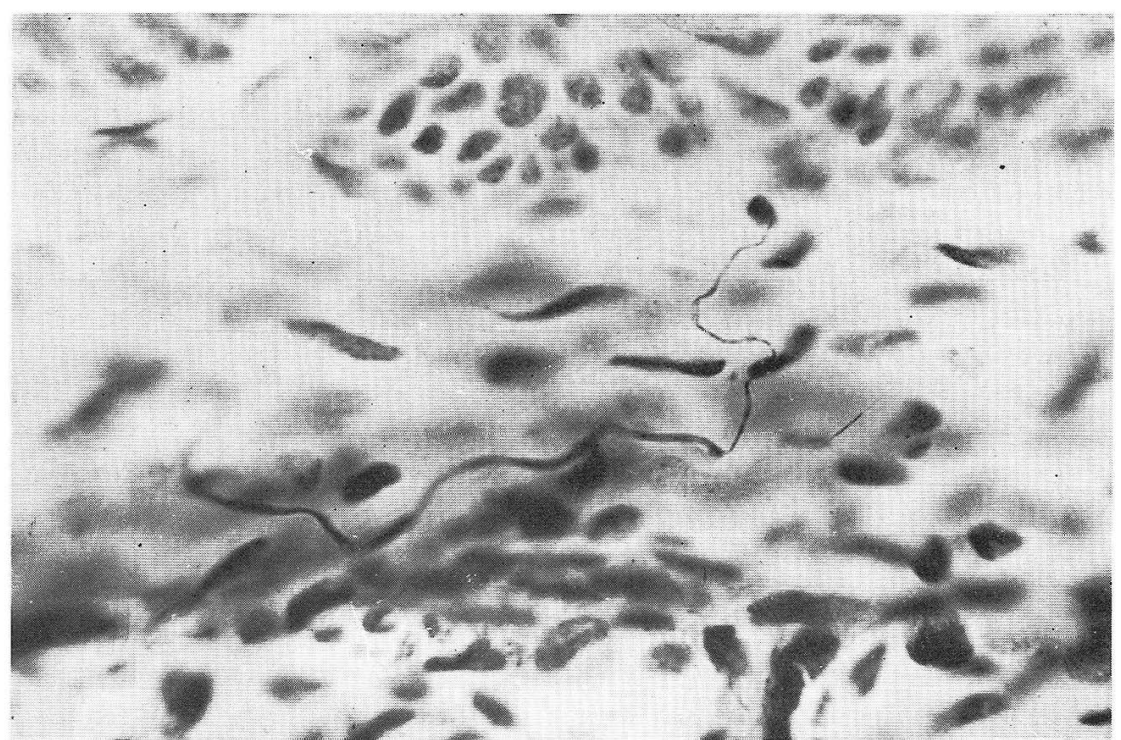

Fig. 20. Higher magnification of the right side of Fig. 19. Photo $\times 600$.

graph of one of the terminal fibres, the one running toward the right edge of Fig. 19. Such intrasubmucosal and intraproprial sensory terminations in the esophagus of Formosan macaque are rather inferior in terminal mode to those in man, but not rarely some terminations composed of $7-8$ terminal branch fibres are also present; in general the terminations here are somewhat more complex than in dog, goat and snapping turtle.

SASYBIN (1930), IWANOW (1930) and FUKUI (1955) reported on intraepithelial fibres found in the esophagus, but in my study 1 found none of them, as no one of this laboratory has ever found in the esophagus of any animal. Neither could I discover any more complex corpuscular termination in the lamina propria, such as the glomerular terminations found by SADA in the human esophagus, in my specimens.

\section{Summary.}

In the esophagus of Formosan macaque, no esophageal glands could be found existing. The tunica muscularis is striated nature in the upper part of the esophagus but comes to be replaced by smooth musculature in the lower part, and in the lowermost $1 / 6$, the muscularis entirely consists of sheer smooth musculature.

The nerve fibres coming into the esophagus form the periesophageal plexus provided with small ganglia in its adventitia.

AUERBACH's plexus in the upper part of the esophagus of this animal is very ill developed, but in the mid-part and below it considerably gains development. The ganglion cells forming the ganglia in the plexus were found to be of DOGIEL's Type I and of apolar or infantile type, no DOGIEL's Type II cells being ever found. The ganglia of MEISSNER's plexus are hetter developed in the upper than in the lower 
part of the esophagus and contain cells usually of infantile type but sometimes of DOGIEL's Type I.

The vegetative fibres distributed in the esophagus comprise very fine sympathetic fibres and somewhat thicker parasympathetic fibres, and forming terminal reticula (STÖHR) as their terminations, come into control by contact over the tissue cells supplied, as in the case with man and the other animals studied hitherto.

The motor fibres supplied to the striated muscle tissue of the esophagus of the Formosan macaque end either in grape-like terminations prevalent in the human esophagus or quite as often in motor end-plates that are in predominance in the caprine esophagus. From this we may infer that the macaque stands just mid-ways between man and goat in this respect.

The sensory fibres supplied to the esophagus of the macaque consist in thicker fibres than motor fibres and form their terminations in all the layers of the esophagus.

In the tunica muscularis are found unbranched and simple branched sensory terminations, particulary often in the intermuscular connective tissue septa. Their fibres usually are smooth surfaced thick ones frequently changing size and show more or less conspicuous glomerular arrangement. Their terminal areas contain a few specific cell nuclei. Branched terminations composed of terminal fibres showing no looping in their courses, however, were not rare either. Besides some branched terminations are formed by side branches sent out from the stem fibres into the tunica muscularis in their courses toward the submucosa. It is of deep interest that branched terminations ending after running winding courses specific to sensory fibres are found in the striated muscle tissue in the upper esophagus.

Rather complex branched terminations are found in the ganglia of AUERBACH's as well as MEISSNER's plexus. In these, the many branch fibres show conspicuous change in size, run looped courses and spread out over rather large areas, ending in blunt or sharp points. It is of special interest that terminations in glomerular arrangement are not rare, either.

Unbranched and simple branched sensory terminations of fibres running conspicuous snake-like courses are found in the submucosa.

Unbranched and simple branched terminations were found in the lamina propria mucosae, too, but here the courses of the terminal fibres are not very wavy, the fibres ending in sharp points just beneath the epithelium. No intraepithelial fibres were ever found in the esophagus of the monkey.

The sensory terminations formed in the esophageal wall of the Formosan macaque described above are inferior in structure to those in man, but generally superior to those in dog, goat and snapping turtle.

\section{内 容自 抄.}

台湾猿の食道には食道腺は証明されない。食道の筋層は食道上部では横紋筋組. 織から成るが，下方に向うに從って次第に平滑筋組織に置き換えられ，下部 1/6 では全く平滑筋のみで構成される。

食道に対する外来性神経線維は外膜内に食道周囲神経叢を形成する。乙の神経 
叢内に多くの交感性の小神経節が含まれる.

Auerbach 神経叢の発達は食道上部では劣勢であるが，中部以下では比較的良好 となる。乙の神経叢内の神経節細胞は専ら Dogiel I 型及び幼若型細胞で表わさ れ, Dogiel II 型細胞は殆ど見られない. Meissner 神経譜内の神経節は食道下部に 於けるよりも上部に於て発達良好，そして專ら幼若型細胞を所有するが，又稀な らず Dogiel I 型細胞をむ含む.

食道に分布する植物神経線維は甚だ微細な交感神経線維とそれより稍々太い副 交感神経線維とから成り, 之等は遂に終網（Stöhr）に移行, 組織細胞に対し接触 的支配関係を示す.

食道筋層の横紋筋に対する運動神経線維は人の食道で多数見られる葡萄状終末 （定）と山羊で多数見られる運動性終板とに移行するが，両者は略々同数に発見さ れる. 即ちこの点からすると台湾猿は山羊よりも遙汃人に近いという事になる。

食道に分布する知覚神経線維は運動性線維より一般に太く, その終末は食道壁 の全層内に発見される，筋層特に筋束間結合織内には非分岐性及び単純性分岐性 終末が見られるが，之等の多くは表面平滑で径の変化に富んだ太い線維から成り， 多少糸球状を呈する。そしてその終末領域内には少数の特殊細胞核を含む. 然し 糸球状を呈さぬ分岐性終末及び粘膜下膜に向う太い幹線維加ら岐れた側枝によっ て作られる分岐性終末む筋層内に稀ならず証明される. 其他食道上部の横紋筋組 織内に特殊な迁曲走行を示す終末枝から成る分岐性終末の見られる事は特に興味 深い.

Auerbach 及び Meissner 神経叢内神経節の中にも稍々複雑な分岐性終末が発見 される. 即ち多数の分岐は著明な径の変化を示しつ」特徵ある係蹄状走行を走り， 可成り広範囲に拡散して鈍状若しくは垁鋭状に終る。尚打終末線維が稀ならず糸 球状配列を示す事は興味深い.

粘膜下膜内には著明な蛇行を示して終る非分岐性及び単純性分岐性知覚終末が 見られる. 又粘膜固有膜内にも非分岐性及び単純性分岐性終末が証明されるが, その終末線維は余り波状走行を取る事なく，その先端は專ら上皮直下に尖鋭状に 終る.上皮内線維はこの動物の食道でも決して証明されない.

以上台湾猿の食道壁に見られる知覚終末の発達は人に此すればより劣勢, 然し 犬，山羊，及びスッポンに於けるよりは概ね良好である。

\section{References.}

Abe, Sh.: On the histology and the innervation of the oesophagus and the first forestomach of goat. Arch. hist. jap. 16 (1959). - Bartlakowski, J.: Untersuchungen über den Bau der Speiseröhre bei Prosimimer-Primaten. Morph. Jb. 65 (1930). - Boeke, J.: Innervationsstudien. V. Der sympathische Grundplexus und seine Beziehungen zu den quergestreiften Muskelfasern und zu den Herzmuskelfasern. Z. mikr.-anat. Forsch. 34 (1933). Fukui, T.: Contributions to histological studies on the peripheral nerve in the esophagus. 
J. Kyoto pref. med. Univ. 58 (1955). - Goetsch, E.: The structure of the mammalian oesophagus. Amer. J. Anat. 10 (1910). - Greving, R.: Die Innervation der Speiseröhre. Müllers Lebensnerven und Lebenstriebe. Berlin, J. Springer, 1931. - Harting, K.: Über die Beteiligung des Nervus vagus an der Bildung der intramuralen Nervengeflechte des Oesophagus. Z. mikr.-anat. Forsch. 35 (1934). - Hirano, N.: Histologiche Untersuchungen über die nervöse Innervation der menschlichen äußeren Augenmusckeln. Graefes Arch. 142 (1941). - Hoshina, K.: On the nerve supply of pharynx and oesophagus of snapping turtle. Arch. hist. jap. 15 (1958). - Ishisawa, M.: Sur l'existence des cellules nerveuses dans les plexus nerveux sous-muqueux de l'oesophage humain. C. r. Soc. biol. 121 (1936).-Iwanow, I. F.: Die sympathische Innervation des Verdauungstraktes einiger Vogelarten. Z. mikr.-anat. Forsch. 22 (1930). - Jabonero, V.: Etudes sur le systéme neurovégétatif périférique. V. Innervation de l'oesophage humain. Acta anat. 15 (1952). - Kolosova, S. I. : Die Entwicklung der afferenten Innervation des Oesophagus des Menschen. Arch. Anat. (Moskva) 31 (1954). Cited from Stöhr. - Kumagawa, H.: Über die vegetativen und motorischen Nerven in der Zungenspitze beim Menschen. J. orient. Med. 34 (1941). - Lawrentjew, B. J.: Experimentell-morphologische Studien über den feineren Bau des autonomen Nervensystems II. Über den Aufbau der Ganglien der Speiseröhre nebst einigen Bemerkungen über das Vorkommen und die Verteilung zweier Arten von Nervenzellen in dem autonomen Nervensystem. Z. mikr.-anat. Forsch. 18 (1929). - Nonidez, J. F.: Afferent nerve endings in the ganglia of the intermuscular plexus of the dog's oesophagus. J. comp. Neur. 85. (1946). - Oppel, A.: Lehrbuch der vergleichenden mikroskopischen Anatomie der Wirbeltiere. II. Jena, G. Fischer, 1897. - Ottaviani, G.: Osservazioni istoanatomiche e sperimentali sulla innervazione dell'esofago di alcuni mammiferi. Z. Zellforsch. 27 (1937). Riegele, L. : Über die Innervation der Hals- und Brustorgane bei einigen Affen. Z. Anat. 80 (1926). - Sabussow, N. P.: Zur Frage nach der Innervation des Schlundkopfes und der Speiseröhre der Säugetiere. Anat. Anz. 44 (1913). — Sada, T.: Mikroskopische Studien zur Innervation der menschlichen Speiseröhre. (Jap.) Psychiat. et Neurol. jap. 46 (1942). Sasybin, N.: Über die Regeneration der Nervenfasern im mehrschichtigen Plattenepithel. Z. mikr.-anat. Forsch. 22 (1930). - Slawik, F. F.: Über das Vorkommen von Muskelspindeln in der Muscularis propria des menschlichen Oesophagus. Anat. Anz. 93 (1942). Stieve, H.: Verhornungserscheinungen im Epithel der menschlichen Speiseröhren- und Scheidenschleimhaut. Z. mikr.-anat. Forsch. 24 (1931). -- Stöhr, Ph.jr.: Beobachtungen zur Histopathologie des Muskel- und Nervengewebes im menschlichen Ösophagus. Z. Anat. 114 (1949). - Möllendorffs Handbuch der mikroskopischen Anatomie des Menschen. Bd. 5, 5. Teil. Berlin, Göttingen u. Heidelberg, Springer, 1957. - Sugamata, G.: Innervation of inferior oesophagus and pars cardiaca ventriculi in dog. Arch. hist. jap. 7 (1955). Sunder-Plassmann, P.: Über den Nervenapparat des menschlichen Glottisöffners, M. cricoarytaenoideus posticus. Z. Hals- usw. Heilk. 32 (1933). — Yamamoto, T.: Histological studies of the rectum of monkey, with special reference to its innervation. Arch. hist. jap. 11 (1957). - On innervation, especially sensory innervation, of the pars pylorica, the duodenum and the pancreas in Formosan macaque. J. comp. Neur. In press. - Yamamoto, T., I. Ito, T. Ohno, T. Ohyama, H. Omoto a. Sh. Seino: Histology and sensory innervation of transitional and mucosal parts of the lip of monkey. Arch. hist. jap. 14 (1958). - Yamamoto, T., T. Ohno, I. Ito, T. Ohyama, Sh. Seino a. K. Hoshina: On sensory innervation of pars cutanea labii of monkey. Ibid. 15 (1958). - Yamamot, T., T. Nonoguchi, M. Mogi, Sh. Kadowaki a. M. Ohta : On the sensory innervation of the soft palate in Formosan macaque. Ibid. 17 (1959). - Yamamoto, T., T. Ashino, K. Fukase, T. Suenaga a. S. Sekiguchi: Histological study on the innervation, especially. sensory innervation of the anus of Formosan macaque. Ibid. In press. - Yanohara, T.: Anatomical studies of esophagus in clinical point of view. Zibi Rinshyō. 48 (1955). 